надання офіцерам знань 3 основ конфліктології для конструктивного розв'язання життєвих проблем і конфліктних ситуацій у професійно-управлінській діяльності та при охороні громадського порядку.

Технологія формування соціальної компетентності $є$ впорядкованою сукупністю психолого-педагогічних методів, прийомів, засобів, техніки виконання, спільної діяльності учасників педагогічного процесу для досягнення конкретною педагогічного результату - формування соціальної компетентності фахівців ОВС. Структура технології формування соціальної компетентності майбутніх офіцерів MBC містить змістовий i процесуальний компоненти. 3 урахуванням вікових соціально-психологічних особливостей курсантів і слухачів ВНЗ МВС, специфіки професійної підготовки і структури соціальної компетентності, для іiї формування у технології передбачено послідовне та поетапне впровадження педагогічних умов, які забезпечують досягнення мети попередніх етапів і відкривають шлях до подальшого pyxy.

Зазначена технологія найбільш повно відповідає вимогам формування соціальної компетентності, необхідності самореалізації особистості фахівців ОВС у спеціально організованій взаємодії та покликана підвищити ефективність їх підготовки до успішного функціонування в професійному та соціальному середовищі.

Перспективами подальших наукових розвідок $є$ експериментальна перевірка педагогічних умов і технології формування соціальної компетентності слухачів та курсантів вищих навчальних закладів МВС України.

\title{
Література
}

1. Беспалько В. П. Слагаемые педагогической технологии / В. П. Беспалько. М. : Педагогика, 1989. - 190 с. 2. Гузеев В. В. Педагогическая техника в контексте образовательной технологии / В. В. Гузеев. - М. : Народное образование, 2001.128 с. 3. Дичківська І. М. Інноваційні педагогічні технології : [навч. посіб.]/ I. М. Дичківська. - К. : Академвидав, 2004. - 352 с. 4. Кларин М. В. Инновации в обучении / М. В. Кларин. - М. : Наука, 1997. - 246 с. 5. Педагогика : учеб. пособ. [для студ. пед. вузов и педагогических колледжей]; под ред. П. И. Пидкасистого. - М. : Педагогика, 2006. - 608 с. 6. Селевко Г. К. Современные образовательные технологии : [учеб. пособ.] / Г. К. Селевко. - М. : Народное образование, 1998. - 256 с. 7. Сластенин В. А. Педагогика : [учеб. пособие для студ. высш. пед. учеб. заведений] / В. А. Сластенин, И. Ф. Исаев, Е. Н Шиянов; под ред. В. А. Сластенина. М. : Издательский центр «Академия», 2002. - 576 с. 8. Смирнов С. А. Педагогика : педагогические теории, системы, технологии : учеб. пособ. [для студ. высш. и сред. пед. учеб. заведений] / С. А. Смирнов, Е. Н. Шиянов; под ред. С. Л. Смирнова. - [4-е изд., испр.]. - М. : Издательский центр «Академия», 2001. - 512 с.

УДК 371.13.02:808.5

Людмила Топчій

\section{ПЕДАГОГІЧНІ УМОВИ ПІДГОТОВКИ МАЙБУТНІХ УЧИТЕЛІВ-ФІЛОЛОГІВ ДО ФОРМУВАННЯ СОЦІОКУЛЬТУРНОЇ КОМПЕТЕНТНОСТІ УЧНІВ СТАРШИХ КЛАСІВ ГІМНАЗЇ̈}

Топчій Л. С. Педагогічні умови підготовки майбутніх учителів-філологів до формування соціокультурної компетентності учнів старших класів гімназії.

У статті на основі аналізу соціальних перетворень i потреб сучасного суспільства, з одного боку, та вимог і очікувань щодо соціокультурної освіти у старшокласників-гімназистів, з іншого боку, визначено педагогічні умови підготовки 
в педагогічному ВНЗ майбутніх учителів-філологів до формування соціокультурної компетентності учнів старших класів гімназії.

Ключові слова: педагогічні умови, майбутній учитель-філолог, підготовка, соціокультурна компетентність, учні старших класів гімназії.

Топчий Л. С. Педагогические условия подготовки будущих учителей-филологов к формированию социокультурной компетентности учащихся старших классов гимназии.

В статье на основе анализа социальных преобразований и потребностей современного общества, с одной стороны, требований и ожиданий от социокультурного образования у старшеклассников-гимназистов, с другой стороны, определены педагогические условия подготовки в педагогическом вузе будущих учителей-филологов к формированию социокультурной компетентности учащихся старших классов гимназии.

Ключевые слова: педагогические условия, будущий учитель-филолог, подготовка, социокультурная компетентность, учащиеся старших классов гимназии.

Topchiy L. S. Pedagogical conditions of future language and literature teachers' training to develop sociocultural competence of senior grades gymnasium students.

The article represents pedagogical conditions of training in pedagogical higher educational establishments of future language and literature teachers to develop sociocultural competence of senior grades gymnasium students. The conditions were determined on the basis of the analysis of social changes and needs of modern society, on the one hand, and demands and expectations from socio-cultural education of senior grades gymnasium students, on the other hand.

Key words: pedagogical conditions, future language and literature teacher, training, sociocultural competence, senior grades gymnasium students.

Упродовж усієї історії вищої педагогічної освіти існувало бажання вдосконалити підготовку майбутніх учителів. ХХІ століття висуває нові вимоги до підготовки вчителя як особистості й професіонала. Ці вимоги пов'язані 3 соціокультурними тенденціями сучасності, де? 3 одного боку, спостерігаються світові глобалізаційні процеси, зближення країн і народів, посилення їх взаємодії в соціальній і культурній сфері, 3 іншого боку, все більше уваги приділяється збереженню самобутнього в культурі кожного народу.

Різноманітні аспекти формування соціокультурної компетентності в майбутніх учителів були предметом уваги ряду вітчизняних і зарубіжних науковців (Т. Жукова, М. Пушкова, С. Саннікова, В. Сафонова, О. Семеног, С. Шехавцова та ін.). Натомість аналіз сучасного стану підготовки майбутніх учителів-філологів засвідчив, що існують проблеми із забезпеченням своєчасної соціальної орієнтації вчителя і його соціокультурного розвитку у швидкозмінюваних довколишніх соціумах; система підготовки недостатньо орієнтує вчителя на усвідомлення себе виконавцем соціального замовлення суспільства; не готує до здійснення соціокультурної освітньої діяльності в різних типах навчальних загальноосвітніх закладів.

На думку багатьох вітчизняних і зарубіжних дослідників (В. Андреєв, О. Горошкіна, С. Караман, Є. Полат та ін.), гімназійна освіта в сучасних умовах - це освіта підвищеного типу з ускладненою навчальною програмою, зорієнтована на формування в учнів широкого наукового світогляду, загальнокультурних інтересів. Старша ланка характеризується тим, що підсумовує та узагальнює весь навчально- 
виховний процес гімназійної освіти, формує цілісний світогляд і перспективи на майбутнє. Учні старших класів гімназій здебільшого мають високий інтелектуальний потенціал, розвинені соціальні й пізнавальні мотиви, демонструють високий рівень очікування від здобутої освіти.

Майбутній учитель-філолог повинен бути спроможним сформувати у старшокласників-гімназистів уявлення про мову як національно-культурний феномен, розуміння національної своєрідності української мовної картини світу, знання констант української національної культури, концептуальних лінгвокультурем, виховання поваги до інших етносів, їхніх мов, звичаїв, традицій, культури, історії тощо. Досвід педагогічної роботи в гімназії переконує в тому, що випускникам філологічних факультетів, які не мають спеціальної підготовки до формування соціокультурної компетентності саме у старшокласників-гімназистів, важко дається така діяльність. Вони здебільшого не володіють достатнім рівнем власної соціокультурної компетентності, відчувають прогалини в методичній підготовці, недостатньо обізнані в царині інформаційно-комп'ютерних та інших інноваційних технологій, які $є$ потужним засобом формування соціокультурної компетентності старшокласників і т. ін.

Mema cmammi - детермінувати і теоретично обгрунтувати педагогічні умови підготовки майбутніх учителів-філологів до формування соціокультурної компетентності учнів старших класів гімназії.

Психолого-педагогічна література містить значну кількість дефініцій поняття «педагогічні умови». У психології під педагогічною умовою розуміють «певну обставину чи обстановку, яка впливає (прискорює чи гальмує) на формування i розвиток педагогічних явищ, процесів, систем, якостей особистості» [3, с. 97]. На думку О. Братанич, педагогічні умови є сукупністю об'єктивних можливостей змісту, методів, організаційних форм і матеріальних можливостей здійснення педагогічного процесу, що забезпечує успішне досягнення поставленої мети [1]. Отже, під педагогічними умовами будемо розуміти комплекс засобів, наявних у навчального закладу для ефективного здійснення навчально-виховного процесу.

Першою педагогічною умовою було визначено забезпечення усвідомленості майбутніми вчителями-філологами на рівні переконань вагомості формування власної соціокультурної компетентності і готовність до реалізації соціокультурного складника майбутньої професійно-педагогічної діяльності.

Аналіз наукової літератури засвідчив, що ефективність підготовки майбутнього вчителя-філолога до соціокультурної професійної діяльності насамперед залежить від його усвідомленого позитивного ставлення до професійної підготовки у ВНЗ, від сформованості в нього мотивів, внутрішньої потреби в розвитку соціокультурної компетентності як у себе, так і в учнів. Психологи (А. Петровський, О. Чебикін, М. Ярошевський та ін.) зазначають, що саме процеси мотивації виконують функцію спонукання суб'єкта до діяльності. Процес навчання започатковується розкриттям об'єктивної значущості дії, що формується, і якщо при цьому в суб'єкта відбувається трансформація об'єктивної значущості в суб'єктивну, у нього виникає готовність до включення дії, яка підлягає формуванню, у значущу для нього діяльність (О. Чебикін).

Важливим складником мотиваційної сфери $є$ потреби. Вони $є$ фундаментом, на якому будується поведінка i вся психічна діяльність людини. Актуалізація в навчальному процесі пізнавальної потреби студентів-філологів дає змогу забезпечити формування їхньої соціокультурної компетентності та готовність до професійнонавчальної діяльності. У цьому випадку реалізується важлива умова переходу від потреби до діяльності. 
Виняткове значення в системі мотивації людини належить мотивам. Головними функціями мотивів є спонукання й смислотворення (О. Леонтьєв). Для студента сукупна дія смислотвірних мотивів і мотивів-стимулів, які вплинули на рішення вступити до педагогічного вишу, становить «ядро» його мотиваційної сфери, що реалізується через процес навчання. Для того щоб раціонально спланувати й організувати свою життєдіяльність, студенту потрібно здійснити комплекс дій, для кожної з яких потрібен мотив. Рішення ухвалюються на основі формулювання причин того чи того перебігу або зміни діяльності, і ці формулювання становлять зміст мотивів, залежно від якого виникають різні мотивації. У процесі навчальнопрофесійної діяльності майбутній учитель-філолог формує свою програму досягнення мети навчання, пов'язуючи іiі за допомогою системи мотивів із відповідними зовнішніми впливами (навчальний процес, соціальне оточення, цільові настанови, правила і норми, традиції ВНЗ тощо). 3 огляду на те, що усвідомлене ставлення студентів до професійної підготовленості повинно проходити через той навчальний матеріал, інформаційний зміст якого відповідає потребам, інтересам, прагненням особистості, потрібно враховувати особливості студентського віку у процесі розроблення навчальних планів, змісту лекцій, семінарів i практичних занять із навчальних дисциплін, що забезпечують підготовку майбутніх учителів-філологів до соціокультурної професійної діяльності. Уважаємо, що це є найповнішим утіленням у меті, змісті, формах, методах навчання у вищій педагогічній школі принципів гуманізації освіти, яка за своєю суттю означає визнання студента носієм суб'єктивного досвіду, у контексті якого він сприймає будь-які навчальні й виховні впливи. Гуманізація вищої освіти визначає роль професійних знань, умінь, навичок як засобів, інструментарію самореалізації особистості у процесі оволодіння майбутньою професією.

Набуття професійних психолого-педагогічних i соціокультурних знань, формування власної соціокультурної компетентності, озброєння продуктивними методиками 3 формування соціокультурної компетентності учнів безперечно має позитивний уплив на забезпечення усвідомленої, позитивної мотивації студентів майбутніх учителів-філологів до здійснення соціокультурної професійної діяльності, на їхню психологічну готовність до формування соціокультурної компетентності в учнів старших класів гімназії.

Цілісності й ефективності навчального процесу з підготовки майбутніх учителівфілологів до формування соціокультурної компетентності учнів не буде досягнуто, якщо не реалізувати таку педагогічну умову, як актуалізація міждисииплінарної інтеграції та ї̈ програмно-методичного супроводу у прочесі підготовки майбутніх учителів-філологів до формування соціокультурної компетентності учнів старших класів гімназіі.

Міждисциплінарну інтеграцію розглядаємо як взаємопроникнення змісту різних навчальних дисциплін i створення єдиного освітнього потенціалу шляхом використання інноваційних педагогічних засобів, організаційних форм і методів навчання. Проблема міждисциплінарної інтеграції в освіті представлена в дослідженнях Н. Амінова, О. Афанасьєвої, О. Кучерук, О. Уварова, С. Фоміна, В. Яценко та ін. Звернення до означеної проблеми науковців і практиків цілком обгрунтоване. Відсутність, ненауковість чи недостатність глибини міждисциплінарної інтеграції часто призводять, з одного боку, до дублювання окремих питань у різних науках в умовах дефіциту навчального часу, а з іншого, - до недостатнього засвоєння студентами низки тем 3 дисципліни, знання яких $\epsilon$ обов'язковим. В аспекті започаткованої роботи важливою $є$ диференціація понять «міждисциплінарна 
інтеграція» і «міжпредметні зв'язки». Останнє означає лише використання окремих набутих знань 3 інших дисциплін під час викладання якоїсь певної дисципліни. Наголошуємо на потребі саме взаємозв'язку і взаємодії навчальних дисциплін, що передбачає системне і цілісне набуття знань, формування відповідних умінь і навичок у ході підготовки студентів до соціокультурної професійно-педагогічної діяльності, тобто інтеракції дисциплін.

В оптимізації процесу підготовки майбутніх учителів-філологів значну роль відіграє інтеграція дисциплін психолого-педагогічного, мовознавчого, літературознавчого, культурологічного, методичного блоків та інноваційних спеціальних курсів, що мають вплив на розвиток теоретичного мислення студентів, формування в них здатності до цілісного системного бачення навчального матеріалу, вміння аналізувати, порівнювати й узагальнювати. Взаємодія викладачів різних навчальних дисциплін сприяє формуванню позитивного ставлення до педагогічної діяльності, зорієнтованої на соціокультурний розвиток учнів (мотиваційний компонент), більш повному засвоєнню студентами методичних і соціокультурних знань (когнітивний компонент), умінь i навичок (діяльнісний компонент), що забезпечить їхню підготовку до соціокультурної професійно-педагогічної діяльності під час здійснення навчально-виховної, філологічної, соціокультурної діяльності.

Навчально-методичний супровід навчального процесу розуміємо як планування, розроблення й створення оптимальної системи навчально-методичної документації і засобів навчання, необхідних для забезпечення повного і якісного процесу підготовки майбутніх учителів-філологів до формування соціокультурної компетентності учнів старших класів гімназії. Основними компонентами навчально-методичного супроводу навчального процесу $\epsilon$ навчальна документація i засоби навчання, які у своїй сукупності становлять окремий цілісний компонент загальної педагогічної системи і мають тісні інтегровані зв'язки з усіма іншими ії компонентами, одночасно є носіями змісту навчання й методами його фіксації. Навчально-методичний комплекс (НМК) у широкому значенні - це чітко визначена сукупність навчально-методичних документів, що являють собою модель освітнього процесу, яка згодом буде реалізована на практиці. Традиційний НМК складається 3 двох компонентів: 1) матеріали щодо планування вивчення дисципліни; 2) матеріали методичного забезпечення вивчення навчальної дисципліни. Перший компонент представлений навчальною та робочою навчальною програмою навчальної дисципліни, що є найважливішими складниками її навчальнометодичного забезпечення. До другого компонента належать методичні матеріали: підручники, конспекти лекцій, інструктивно-методичні матеріали до практичних, семінарських і лабораторних занять, до проведення ділових ігор, до самостійної роботи, підготовки до іспитів тощо. Наявність у НМК до дисциплін, що забезпечують фахову підготовку майбутніх учителів-філологів у педагогічному ВНЗ, матеріалів, присвячених соціокультурній підготовці студентів, оптимізує процес підготовки майбутніх учителівфілологів до формування соціокультурної компетентності учнів.

Вивчення наукової літератури та спостереження за навчальним процесом переконали нас у необхідності використання «спеціального набору» форм, методів, прийомів, способів і засобів навчання, який би максимально стимулював пізнавальну активність і самостійність студентів, формував готовність до діяльності, розвивав природні здібності (С. Максименко). У цьому зв'язку було визначено таку педагогічну умову- занурення студентів в активну професійно спрямовану сочиікультурну навчальну і професійну діяльність.

У педагогіці під активним навчанням розуміють таку організацію та ведення навчального процесу, яка спрямована на всебічну активізацію навчально-пізнавальної 
діяльності студентів за допомогою широкого, комплексного використання як педагогічних (дидактичних), так і організаційно-управлінських засобів. На думку А. Вербицького, саме активне навчання формує у студентів пізнавальну мотивацію, при цьому йдеться не про «примус» до активності, а про спонукання до неї; про необхідність створення дидактичних і психологічних умов породження активності особистості в пізнавальній діяльності [2, c. 52]. Відтак, поняття «активне навчання» знаменує собою перехід від переважно регламентуючих, алгоритмізованих, програмованих форм i методів організації дидактичного процесу у ВНЗ до розвивальних, проблемних, дослідницьких, пошукових, що забезпечують породження пізнавальних мотивів, інтересу до майбутньої професійної діяльності, умов для творчості в навчанні.

Оскільки йдеться про фахову підготовку студентів- майбутніх учителівфілологів, передбачається їх залучення до активної професійно спрямованої соціокультурної навчальної і професійної діяльності. Забезпечення цієї умови відбувається такими основними шляхами. По-перше, для студентів була організована спеціальна форма навчання - експериментальний спецпрактикум «нноваційні технології в соціокультурній професійній діяльності вчителя-філолога», що був професійно спрямованим за своїм характером. По-друге, заняття в межах спецпрактикуму були організовані таким чином, щоб максимально активізувати професійно спрямовану соціокультурну навчальну діяльність студентів. Вони характеризувалися такими ознаками: проблемністю; адекватністю навчальнопізнавальної діяльності студентів характеру їх майбутніх практичних (професійних) завдань i функцій, тобто здійснювалося контекстне навчання; взаємонавчанням (стрижневим моментом багатьох форм проведення занять була колективна діяльність i дискусійна форма обговорення); індивідуалізацією (організація навчальнопізнавальної діяльності з урахуванням індивідуальних здібностей і можливостей студента, розвиток у студентів механізмів самоконтролю, саморегулювання, самонавчання); дотримання принципу безпосередності, самостійності у взаємодії студентів із навчальною інформацією (педагог не виконував роль «фільтра», що пропускає через себе навчальну інформацію, а був помічником, керівником їхньої самостійної роботи, реалізуючи принципи педагогіки співробітництва); мотивації (використовували такі мотиви: професійний інтерес; творчий характер навчальнопізнавальної діяльності; змагальність, ігровий характер проведення занять; емоційний уплив). По-третє, студенти залучалися до різноманітних методів активної професійно спрямованої навчально-мовленнєвої діяльності (аналіз конкретних ситуацій із постановкою проблемних питань, диспути, круглі столи, мозковий штурм, моделювання типових професійних соціокультурних ситуацій, ситуаційні, рольові й ділові ігри, тренінги, проектна діяльність, спостереження, самоаналіз). По-четверте, студенти були залучені до професійної соціокультурної діяльності під час проходження ними педагогічної практики в гімназії, де вони реалізовували набуті знання і вміння щодо формування соціокультурної компетентності в безпосередній роботі зі старшокласниками.

Ще однією педагогічною умовою експериментального навчання було визначено забезпечення усвідомлення студентами необхідності рефлексивно-оцінної діяльності у прочесі їхньої підготовки до формування сочіокультурної компетентності учнів старших класів гімназії. Вказана умова зумовлюється суб'єктною парадигмою навчання.

Сучасна психологія трактує рефлексію [від лат. reflexio - повернення назад] як «мислительний (раціональний) процес, спрямований на аналіз, розуміння, усвідомлення себе: власних дій, поведінки, мовлення, досвіду, чуттів, станів, 
здібностей, характеру, стосунків і ставлення до інших, своїх завдань, призначення і т. ін.» [3]. Необхідність високого рівня рефлексивно-оцінної діяльності майбутніх учителів-філологів зумовлюється специфікою їхньої соціокультурної професійнопедагогічної діяльності, що полягає в підготовці їхніх вихованців до життя в різносоціумному, багатоманітному й полікультурному середовищі. У цьому зв'язку необхідно забезпечити розуміння студентами високої відповідальності за (не)готовність / (не)спроможність забезпечити формування соціокультурної компетентності учнів старших класів гімназії. Рефлексивно-оцінна діяльність майбутнього учителя-філолога передбачає осмислення ним власного рівня соціокультурної компетентності, усвідомлення відповідальності за майбутню професійну діяльність, оцінку стратегій щодо підвищення власних методичних досягнень.

Послідовна реалізація визначених педагогічних умов покликана забезпечити оптимізацію навчального процесу 3 підготовки майбутніх учителів-філологів до формування соціокультурної компетентності в учнів старших класів гімназії.

\section{Література}

1. Братанич О. Г. Педагогічні умови диференційованого навчання учнів загальноосвітньої школи : дис. ... канд. пед. наук : 13.00 .09 / О. Г. Братанич; Криворізьк. держ. пед. ун-т. - Кривий Ріг, 2001. - 238 с. 2. Вербицкий А. А. Активное обучение в высшей школе: контекстный подход / А. А. Вербицкий. - М. : Высшая школа, 1991. 207 с. 3. Краткий психологический словарь / Сост. Л. А. Карпенко; под ред. А. В. Петровского, М. Г. Ярошевского. - Ростов н/Д. : Феникс, 1998. - 512 с.

УДК 801.73

Елла Часова, Віталій Івчук

\section{ОСОБЛИВОСТІ ПІДГОТОВКИ МЕТОДИЧНИХ ПОСІБНИКІВ 3 ХІМІЇ ДЛЯ НАВЧАННЯ СТУДЕНТІВ-ІНОЗЕМЦІВ}

Часова Е. В., Івчук В. В. Особливості підготовки методичних посібників 3 хімії для навчання студентів-іноземців.

Розглянуто деякі питання підготовки навчальних посібників 3 хімії для студентів-іноземців підготовчого відділення. Запропоновано ефективний навчальний посібник, спрямований на інтенсифікацію процесу вивчення хімії, що містить навчальний тлумачний термінологічний словник хімічних термінів українською, російською, англійською, французькою та арабською мовами.

Ключові слова: хімія, викладання хімії, студенти-іноземці, методичний посібник.

Часова Э. В., Ивчук В. В. Особенности подготовки методических пособий по химии для обучения студентов-иностранцев.

Рассмотрены некоторые вопросы подготовки учебных пособий по химии для студентов-иностранцев подготовительного отделения. Предложено эффективное учебное пособие, направленное на интенсификацию процесса изучения химии, которое содержит учебный толковый терминологический словарь химических терминов на украинском, русском, английском, французском и арабском языках.

Ключевые слова: химия, преподавание химии, студенты-иностранцы, методическое пособие.

Chasova E. V., Ivchuk V. V. Peculiarities of training manuals on chemistry for teaching foreign students. 